\title{
De grenzen van organisatiecriminaliteit
}

Citation for published version (APA):

van den Heuvel, G. (2017). De grenzen van organisatiecriminaliteit. Maastricht University. https://doi.org/10.26481/spe.20170421gh

Document status and date:

Published: 21/04/2017

DOI:

10.26481/spe.20170421gh

Document Version:

Publisher's PDF, also known as Version of record

\section{Please check the document version of this publication:}

- A submitted manuscript is the version of the article upon submission and before peer-review. There can be important differences between the submitted version and the official published version of record.

People interested in the research are advised to contact the author for the final version of the publication, or visit the DOI to the publisher's website.

- The final author version and the galley proof are versions of the publication after peer review.

- The final published version features the final layout of the paper including the volume, issue and page numbers.

Link to publication

\footnotetext{
General rights rights.

- You may freely distribute the URL identifying the publication in the public portal. please follow below link for the End User Agreement:

www.umlib.nl/taverne-license

Take down policy

If you believe that this document breaches copyright please contact us at:

repository@maastrichtuniversity.nl

providing details and we will investigate your claim.
}

Copyright and moral rights for the publications made accessible in the public portal are retained by the authors and/or other copyright owners and it is a condition of accessing publications that users recognise and abide by the legal requirements associated with these

- Users may download and print one copy of any publication from the public portal for the purpose of private study or research.

- You may not further distribute the material or use it for any profit-making activity or commercial gain

If the publication is distributed under the terms of Article $25 \mathrm{fa}$ of the Dutch Copyright Act, indicated by the "Taverne" license above, 
Grat van den Heuvel

Faculty of Law

\section{De grenzen van organisatiecriminaliteit}




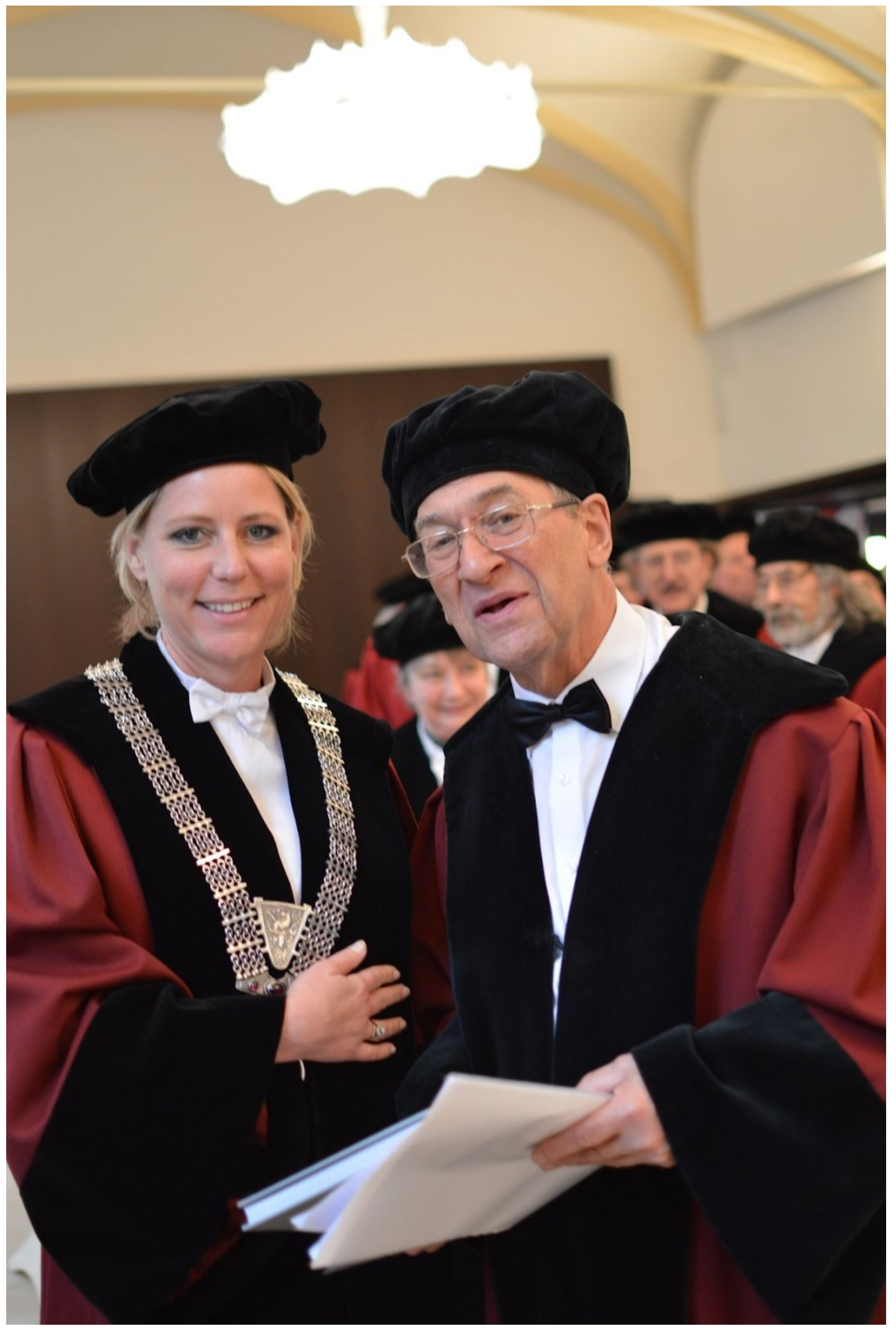


MAASTRICHT U NIVERSITY

Faculty of Law

De grenzen van organisatiecriminaliteit

Grat van den Heuvel

Afscheidscollege

21 april 2017 
Hooggeachte rector magnificus, hooggeachte decaan, geacht stichtingsbestuur, geachte collegae, studenten en ex-studenten. Lieve familie en vrienden.

Ik wil beginnen met een kort woord van excuses en dank. Excuses omdat ik deze rede zo laat hou, en dank voor alles wat ik van de faculteit en universiteit gekregen heb, tot en met dit laatste geduld met mij.

Kort na mijn pensionering vond ik onderdak bij Mundo, het buitenland bureau van onze universiteit. Die zochten iemand ter voorbereiding van juridische projecten in Indonesië. Nu had ik voor Ontwikkelingssamenwerking tussen ' 86 en '92 meegewerkt aan een aantal juridische upgrading projecten in dat land. Dit nieuwe project bij MUNDO betrof het omvormen van de Law School van Udajana University in Den Passar, naar Maastrichts onderwijs en organisatie model. Het project werd toegekend en verliep prima met veel dank aan de faculteit en aan Hennie Sijen, Han Aarts, en de andere vrienden van MUNDO.

Tragisch was wel het plots overlijden in Den Passar van onze collega Peter Bal. Zowel hier, als ginds herinneren we Peter als een enthousiaste en innemende vriend en een uitstekende docent. Dit soort zaken, naast enkele fysieke problemen, maakten dat ik nauwelijks in de gaten had dat ik al een tijd met pensioen was zonder afscheid. Vandaar mijn dank alsnog een afscheidsrede te mogen houden. Ik koos als titel:

De grenzen van organisatiecriminaliteit

Voor dit thema heb ik gekozen omdat ik organisaties al een leven lang interessant vond. Voor ik naar Maastricht kwam, was ik 7 jaar medewerker rechtssociologie bij Toon Peters in Utrecht en daar speelden organisaties een hoofdrol, zowel in onderzoek als onderwijs. Mijn proefschrift betrof een onderzoek naar de mogelijkheden en beperkingen van burgerschap binnen organisaties. 
Kortom ik zag vooral het positieve van organisaties. Toen kwam ik in 1983 naar Maastricht voor de criminologie, wat ik al snel vertaalde als het kijken naar het negatieve achter organisaties: de organisatie criminaliteit. Dat onderwerp is op zich zo oud als de criminologie zelf, lombroso was immers van 1880, en al rond 1900 schreven met name Amerikaanse sociale wetenschappers als Veblen en Ross uitvoerig over de misse daden van de toenmalige groot industrieën. Ze noemden hen "Roofzuchtige geldwolven", en verweten hen vooral machtsmisbruik. De captains of Industry meenden boven de wet te staan, en dat klopte ook wel. Men hoeft maar de cartoons uit die tijd te bekijken om te beseffen dat meer mensen zo over die Captains dachten. Met die Veblen en Ross liep het overigens wel fout af. Ze werden ontslagen als hoogleraar aan Standford University, met name vanwege hun publicaties.

Vijftig jaar later deed Donald Sutherland dat soort onderzoek nog eens over, alleen veel uitgebreider en minder moralistisch. Maar ook hij had geen geluk. Niemand wou zijn studie uitgeven. Pas na het schrappen van de namen van de betrokken firma's en bestuurders, durfde Dryden Press het aan, het uit te geven. White Collar Crime werd gepubliceerd in 1949, maar werd pas beroemd in 1983. Toen verscheen White Collar Crime, the uncut version. Toevallig ook het jaar dat ik naar Maastricht kwam. En ik viel met de neus in de boter want in die tijd verschenen er plots tientallen Readers en Handboeken over Business and Governmental crimes. Deels leken die op elkaar. Ze gaven veel casuïstiek en zochten daarbinnen naar daders en hun daden. Organisatiecriminaliteit kwam naar buiten als een veelkoppig monster dat nauwelijks te temmen viel omdat men - die organisaties zelf de regie voerde over hun eigen grenzen. De interpretatie van wat wel en niet mocht, over wat kon en niet kon wilde men zelf bepalen. Kortom, baas in eigen sector. De bedrijfsethiek op zijn "business schools" was geboren.

Ik noem het veelkoppig omdat de zaken die in die handboeken en readers behandeld werden, een ruim palet besloegen: geknoei met 
medicijnen, unlawfull risk taking achter allerlei zware ongelukken van omgeslagen veerboten tot giframpen in India -, van gevaarlijk werk tot milieurampen. Zoveel organisaties als er waren, zo veelzijdig was ook het misbruik. De meeste auteurs kwamen tot de conclusie dat organisatie criminaliteit een wat verstopte vorm van misdaad is, die pas achteraf blijkt, en altijd gepleegd door schijnbaar keurige mensen in keurige organisaties.

Een klassiek voorbeeld dat veel genoemd werd was de toen zeer recente Savings and Loans crisis die in de jaren ‘80 I'90 in de VS speelde. Die crisis begon met de bank liberalisering door de regering Reagan. Die liberalisering gaf iedereen de vrijheid een kleine spaar en leenbank te beginnen, waarbij de overheid het spaargeld tot een zeker bedrag verzekerde, en de oprichter slechts een klein startkapitaal, maar verder geen papieren hoefde te hebben. Het resultaat was voorspelbaar. Er volgde eerst een hausse aan nieuwe kleine spaar en leenbanken, iedere buurt zijn eigen bank. Maar even voorspelbaar volgde daarna een hausse aan faillissementen, soms al na één of twee jaar. Met name omdat de oprichters hun eigen bank grotendeels hadden leeggegeten via idioot hoge salarissen enerzijds, en hypotheek fraudes anderzijds. Crawford, hoofd banking control in de staat California, werd wereldberoemd met de statement "The best way to rob a bank is to own one ". Dan pak je heel wat meer, dan bij een gewone bank robbery. In feite was dit niet meer stelen ván de bank, maar dóór de bank zelf.

De overheid, zo concludeerden veel onderzoekers toen, had dit misbruik zelf uitgelokt, maar de oprichters hadden er ook iets te gretig misbruik van gemaakt en hun "verdiensten"vanaf het begin direct naar hun collega's op Kaaiman achtige oorden verhuisd. De schuld aan de gemeenschap, de publieke zaak, voor dat "savings and loans debacle" liep overigens wel in de biljoenen. En dat was toen heel veel. Later - na de 2008/ 2009 crisis - keek men nogs eens terug op ook die oudere onderzoeken, een soort meta analyse inzake fout 
bankieren een kwart eeuw later. Toen concludeerden ze dat ze in die jaren '80 nogal naïef waren geweest. Vooral het verschil in denken over preventie toen en nu viel hen op. Zij dachten toen vooral aan: veel harder aanpakken, die hoge heren. Strenger en veel langer straffen en hogere boetes. Er moest efficiënt vergolden worden. Terwijl men zich nu eerst en vooral afvraagt: waar valt wat te leren binnen die toenmalige bancaire puinhoop -inzake een veiliger of een eerlijker bankieren? Hoe kunnen we preventie echt realiseren, zodat dit zich nooit meer herhaalt? Want voor vergelden koopt men weinig. Dat belemmert vaak preventie

De onderzoekers toen, kwamen anno 2009 in onverwachte zijstraten terecht, zoals bij de Airline Safety Control. Het vliegen is er de laatste eeuw zeker veel veiliger op geworden, hoe men er ook tegenaan kijkt. Waar lag dat aan? Aan een responsibility opvatting, die vóóruit kijkt en niet achterom. In de luchtvaart worden fouten en bijna crâches gemeld en uitvoerig geanalyseerd, niet om iemand te bestraffen, maar om meer veiligheid in de toekomst te realiseren. Om de branche safer te maken.

De bank-crisis van 2008 begon in de VS, maar kreeg al snel wereldwijde consequenties. Ze werd aangevoerd door grote systeembanken als Lehman Brothers en Goldman Sachs. Dat was andere koek dan die Savings and Loans banken uit de jaren '80. Beursmanipulatie speelde daarbij de hoofdrol. Het zg. "flitskapitaal", het echt grote geld dat systeembanken rond pompten, bleek door verknipping en dan nog eens verknippen en dan meedoen met put opties, oncontroleerbaar maar ook onbeheersbaar. Men verkocht die vehicles aan allerlei staten en landen, wat daar weer leidde tot ingestorte huizenmarkten en - zoals bv. In Griekenland - in een geplofte economieën. De echte omvang van die schade begint nu pas, een decennium later, enigszins duidelijk te worden.

Een deel van het grote geld van Russische, Amerikaanse, Koreaanse of Chinese tycoons is wellicht niet erg eerlijk verworven, maar via de wanpraktijken van die systeembanken, aangevoerd door de VS, is het ook even snel weer in zeepbellen op gegaan. 
Ook grote westerse banken - in Engeland, lerland, ljsland, maar ook Nederland - deden mee aan die carrousel. Het zg. rondpompen van "bad products" werd door minister Bos later als hoofdreden genoemd waarom banken als ING en ABN AMRO overheidssteun moesten vragen en krijgen, wilden ze niet omvallen. Maar dat het zover kon komen, werd in feite alleen gelegitimeerd met de verwijzing naar het gegeven, dat de Amerikaanse waakhond dat rondpompen had goedgekeurd. Blijft de vraag naar een soort financiële Aviation Authority, zodat banken echt kunnen leren van eigen fouten.

Tot hier had ik het vnl. over Angelsaksische landen. Dat is omdat b.v. in óns land kartels lange tijd gewoon toegestaan waren, mits maar gemeld bij de overheid. Pas na 1992 - een eeuw na de VS - besefte men dat vrijhandel en gelijke speelvelden zich slecht verdroegen met kartels, en werd het beleid stapsgewijs aangepast. Het duurde tot 1998 eer ook ons land zich bij dat algeheel verbod op kartels had aangesloten. De controle daarop en op het gedrag van de financiële markten in het algemeen, kwam bijgevolg in ons land ook pas zeer laat op gang.

Onze systeembanken vroegen de overheid om hulp en kregen die. Maar van een echte shift van de private naar de publieke zaak was hier geen sprake. Bos en later Dijsselbloem mochten vooral voorschieten en er zou op tijd terugbetaald worden Maar dat duurde dus langer dan verwacht. En na afloop bleek er aan de bedrijfsvoering ook minder veranderd dan wat afgesproken was. Er was vooral organisatorisch bezuinigd, veel lokale kantoren waren gesloten en lager personeel was afgevloeid of overgeplaatst. Maar van echt bakens verzetten was hier geen sprake. De overheid had het ook niet gezien als een kans op meer invloed. Dat gold overigens ook elders zoals in de U.K. Ook in Londen waren banken gered door de overheid, maar om nu te zeggen dat die periode gebruikt was om grondig schoon schip te maken, nee. Joris Luyendijk was drie jaar gastredacteur bij de Londense krant The Guardian, om de werking 
van The City - het geld centrum - te analyseren en te beschrijven. Hij was geschrokken. De geldhonger bij die Londense bankiers leek op een onuitroeibare besmettelijke ziekte. Niet alleen waren de bonussen weer even hoog als voor de crisis, maar ook het speculeren met andermans geld kende geen grenzen. Naast riante salarissen en een levensstijl die in de wilde jaren '20 van de vorige eeuw niet zou hebben misstaan, leek alles op de tijd van vóór de crisis. Hij noemde zijn boek veelzeggend "...dit kan niet waar zijn", maar dat was het dus wel. Witteboordencriminaliteit kent geen grenzen zo bleek maar weer eens. Als je hem leest lijkt het of we terug zijn in de dagen van Ross en Sutherland. De baas van de Nederlandse Bank kan nog zo vaak op TV komen; de banken controleren nog steeds voornamelijk zichzelf. Ze pochen met hun internationale speelveld maar het is wel een spel zonder scheidsrechters.

Zelfs de fiscus speelt mee en beschermt de 100.000 brievenbusfirma's aan de "Zuidas" . Firma's "met kamerplant", want de fiscus eist dat de firma hier ook echt gehuisvest moet zijn, wat o.a. kan blijken uit het onderhoud van tenminste één kamerplant per firma op zo'n adres.... Ik dacht eerst: dit is een grap uit de tijd van Dieter Brüll (hoogleraar fiscaal recht uit Amsterdam die van grapjes hield). Maar het bleek nog waar te zijn ook.

Een enkele keer spelen individuen van boven het maaiveld heel persoonlijk de shift van privaat naar publiek.

Twee klassieke zaken: prins Bernhard en Helmut Kohl. Prins Bernhards betrokkenheid bij het Lockheed schandaal vond plaats in een tijd dat maar weinigen konden geloven dat hij voor harde corruptie, fiscale fraude en hoop smeergeld de echtgenoot van onze toenmalige Koningin, beslist niet terugdeinsde. Dat idee viel als het ware buiten de fantasie. Hij heette onze beste ambassadeur in het buitenland, zowel voor het bedrijfsleven als voor de dieren. En dan ineens valt dat bericht uit Washington bij Den Uijl op tafel....en u kent het verhaal verder. 
Decennia later speelde in Duitsland de zaak Helmut Kohl. Die had CDU fondsen stiekem op Lichtensteinse banken gestald om belasting te ontduiken. Ook dat konden veel Duitsers aanvankelijk niet geloven, tot hij het zelf toegaf. Beide zaken zijn opgelost door discrete onderhandelingen. Maar veel toeschouwers bleven achter met dat katerig gevoel van "dat had ik van U niet verwacht!" Met name het feit dat de publieke dimensie meespeelde in het afhandelen van deze private zaken verbaasde. Immers Bernhard en Kohl verklaarden hun gedrag achteraf als "eigenlijk" een dienst aan de publieke zaak met als argument: "wij deden het heus niet voor onszelf, wat denkt u wel van ons?." Kortom, klassieke voorbeelden van "denial".

Hetzelfde argument speelt overigens vaak bij witteboorden zaken. Van der Valk, Van de Nieuwenhuyzen, Hooijmijer, Van Reij... allen verklaarden dat de zaak in eigen ogen toch niet zo heel erg verkeerd leek en dat, als gezegd, het uiteraard ging om de publieke zaak te dienen.

Ik stap over naar mijn stokpaardje, de collusie, die heimelijke verstandhouding tussen publiek en privaat richting illegalibus en waarbij dat "heimelijk" slaat op "iets illegaals"; iets dat verder niemand hoeft te weten. Van Dale voegde eraan toe dat dit nietweten bedoeld was om het opsporen van strafbare feiten te belemmeren. Maar het is natuurlijk al collusie als men samen iets illegaals doet of wil doen, en als er nog niemand aan het opsporen is.

Mijn eerste uitvoerige betoog hierover schreef ik in 1990, voor de oprichtings conferentie van de Indonesian Society of Criminology. Het had als titel "Corporate crime in East and West; in search of collusion". Ik deed daarin wat iedereen toen deed, case studies geven. Zo schetste ik het failliet van de Indonesische Bank Duta, die de kleine middenstand op Java enorm had gedupeerd, en het Japanse Minimata schandaal. Dat betrof een langdurige kwikvergiftiging van de baai van Minimata, (door Chisso industries). Beiden waren 
voorbeelden van hoe de overheid een foute private partij extreem ondersteunde en tegen vervolging en schadeclaims beschermde. Terwijl er heel veel mensen gedupeerd door waren. In Japan ging het uiteindelijk zelfs om honderden doden.

In 1993 had ik het onderwijsboek "Onderhandelen of straffen; over organisatiecriminaliteit en overheidscontrole" geschreven. Want inderdaad fout overheidsgedrag bleef me fascineren. Ik typeerde in dat boek collusie als vooral een risico, een typisch gevaar bij coöperatieve onderhandelingen en controleactiviteiten. Als het té goed klikt bij die coöperatie is het gevaar van "afglijden" levensgroot. Een succesvolle inspecteur heeft vaak niet in de gaten dat men steeds minder kritisch aan het worden is. Soms begint dat heel klein, bv. inspecteurs van het landbouwschap hadden op hun naamkaartje staan, landbouwadviseur ipv. landbouwinspecteur, wat ze wel waren. Maar inderdaad hun stijl van controleren was vooral adviserend.

In 1997 hield ik mijn oratie over "Collusie en bedrijf, een vergeten hoofdstuk uit de organisatiecriminologie". In die rede legde ik met name uit waarom ik het een typische Nederlandse vorm van organisatiecriminaliteit vond, die nodig nader onderzoek verdiende. Wij zijn geen typisch fraude of corruptie land, zoals Indonesië dat ik een beetje kende. Ze komen wel voor, die twee, maar zijn veel minder typisch Hollands dan dat collusie gedrag, waarbij de private en de publieke sector elkaar als het ware opzoeken om er samen iets moois van te maken, ook als dat eigenlijk illegaal is. Ik noemde collusie toen een typisch afglij risico. Men zat in een soort glijbaan. Belangrijkste blootleggers van collusie waren parlementaire onderzoeken en enquêtes. Ik zag ze als een soort bewijsvoering voor de stelling dat we vooral een collusie land zijn. Daarvoor hoefde men niet naar Indonesië of Japan te gaan. 
Ook hier gebruikte ik vooral voorbeelden. Wie herinnert zich nog De RSV enquête? Die enquête onderzocht de achtergronden waarom men 2.2 miljard subsidie aan een scheepswerf had gegeven die uiteindelijk toch omviel. De overheid had daar als regerings-waarnemer de DG van EZ, de heer Molkenboer als bestuurder aangesteld, op de stoel van Verolme. Die stoel zat zo goed en Molkenboer ging zo op in zijn nieuwe functie dat hij alle subsidie en WIR-fondsen gebruikte voor schepen waar helemaal geen opdracht voor bestond. De onderzoekscommissie sprak van ongecontroleerd geschuif met publieke middelen, en dat met een overgave die aan een speeltafel niet zou hebben weerstaan. Anders was de WAO casus die door de commissie Buurmeijer onderzocht was. Daar bleek dat én de sociale partners én de overheid wisten dat de WAO wet grootscheeps misbruikt werd. Waar plaats was voor 200.000 arbeidsongeschikten, werden er uiteindelijk bijna een miljoen geparkeerd.

Dit soort enquêtes en onderzoeken waren blootleggers omdat men zich in de eerste plaats richtte op netwerken en processen en minder op schuldige natuurlijke personen. Preventie stond voorop. Al hebben uit deze enquêtes bewindslieden soms ook wel hun consequenties getrokken.

Two cheers voor die enquêtes maar geen drie! Immers, enquêtes komen niet uit de lucht vallen. Ze ontstonden meestal naar aanleiding van signalen van klokkenluiders of van koppige onderzoeksjournalisten. Werk dat nu gedaan wordt door rubrieken als Argos, Zemba, of Tegenlicht.

De officiële controleurs van de private sector met hun witte boorden, zoals notarissen en accountants, gaven nooit suggesties richting nader parlementair onderzoek. Ik zou haast zeggen, het tegendeel moet maar eens gebeuren. Zij zouden zelf juist wat vaker en grondiger tegen het licht gehouden moeten worden om te achterhalen of men wel zo onpartijdig is als men beweert te zijn. En of men de publieke zaak wel op een eerlijke manier dient. 
Onze bijdrage aan de parlementaire enquête "De bouw uit de schaduw" was voor mij leerzaam omdat ik deze keer van heel dichtbij zag hoe Hollandse collusie praktijken het eeuwig leven leken te hebben. De Nederlandse politieke cultuur zoekt collusie op! Kroes, Jorritsma en Peijs waren minister van Verkeer en Waterstaat, terwijl hun echtgenotes, partner waren in de grote bouwwereld die het juist van overheidsopdrachten moest hebben. Publiek en privaat in één bed en heus niet met Chinese muren daartussen. Wat voor buitenstaanders onbegrijpelijk leek, was (en is m.i. nog steeds) in Den Haag heel gewoon. Minister Eurlings onderhandelde de ene dag met de bazen van KLM als minister, maar trad kort daarna in dienst als directeur bij KLM Cargo. Er zijn weinig beschaafde landen waar dit soort overgangen zomaar kunnen. Geen bedingen bij het aantreden als minister; niets stond blijkbaar dit soort overstappen in de weg.

Nepotisme, vriendjespolitiek, is een lastig grijpbaar, verwijtbaar en bewijsbaar fenomeen. En het hoeft ook niet altijd samen te vallen met collusie. Maar het lokt wel.

De argumenten waarmee men zich achteraf legitimeerde tijdens die enquêtes, waren vaak van eenzelfde soort: men speelde de vermoorde onschuld. Achter collusie - zo betoogde ik eerder - zitten veel verklaringen en ontwikkelingen. Juridisch kennen we alleen de termen kartel en samenspannen, maar niet collusie. Typische collusie zaken haalden dan ook nooit de strafrechter.

Maar kijken we naar het bredere veld van de organisatie criminaliteit, dan lijkt daar de laatste jaren toch enige beweging in te zijn gekomen. Zo zijn recent onvoorwaardelijke vrijheidsstraffen uitgedeeld aan witte boorden, iets wat 10 of 15 jaar geleden ondenkbaar leek. Overigens, of dat vooruitgang in de zin van preventieve is, waag ik te betwijfelen. Preventie hoort immers bij leerzaam "vooruit kijken" - denk aan onze piloten - en niet bij "vergeldend terugkijken" dat preventie juist belemmerd. Wat dat betreft vind ik het niet erg, als het parket via schikkingen miljoenen vangt, het bedrijf negatieve publiciteit ondervindt en de leiding een 
soort beroepsverbod krijgt en bovendien de hele procedure een stuk korter laat duren.

Terug naar collusie. Ik stelde dat collusie ons Nederlanders na aan het hart ligt. Toen ik daar voor het eerst uitvoeriger over schreef verwees ik met name naar onze historie. Vanaf de Gilden uit de middeleeuwen, tot de zuilenmaatschappij van Oud, Drees en Romme, kortom - vijf eeuwen "accommodation" om met Lijphart te spreken - dat moet sporen achtergelaten hebben in onze landsaard. Als publiek en privaat zo lang "doenbaar" samen kunnen gaan, moet het wel diep zitten. Ik zeg bewust "doenbaar" omdat we wel degelijk een volkje waren vol rivaliserende groepen. Grote maatschappelijke en religieuze geschillen waren aan de orde van de dag, maar werden beheersbaar gehouden. De moderne geschiedenis zijn we ingegaan vol "accommodatie": "eenheid in verscheidenheid" stond er in de vakbonds asbak bij menige herenkapper anno 1950, cadeau van de middenstandsbond.

Maar tegenwoordig leert men op school dat de zuilen maatschappij voorbij is, achterhaald. De krant, de radio, de school, het verenigingsleven, het heet allemaal ontzuild te zijn. Dat zal wel letterlijk wel kloppen, maar de SER is nog steeds zeer invloedrijk, net als de loonakkoorden, en het sociaal en culturele overleg op allerlei niveau's. We hebben meer planbureau's, adviesorganen, meld- en steunpunten, doelgerichte overlegorganen, etc dan ooit te voren. Achter wat eens PBO organen heetten, zitten nu nieuwe overleg graemia voor allerlei branches en sectoren, en jawel, zelfs religieus georiënteerde clubjes komen ook weer voor. Ik wil maar zeggen, de ruimte voor discreet overleg en vooroverleg inclusief het risico op collusie is nog even royaal aanwezig als in de vijf eeuwen voordien. En het achterliggende coöperatie model blijkt nog net zo effectief als wat u leest in "De ambachtsgilden van 's Hertogenbosch voor 1629", om maar eens een willekeurig onderzoek naar collusie uit vroegere dagen te noemen (proefschrift van mijn vader uit 1947.) 
Toen de zuilen definitief gesloopt waren, ontstond een nieuwe slogan met dezelfde pretenties genaamd het "Onderhandelend bestuur". Hoekema noemde Onderhandelend bestuur "een vorm van bestuur waarbij het bestuur samen met derden door middel van onderhandelingen, beleid voorbereide, vaststelde en uitvoerde. Eerder dan recht en wet, eerder dan beginselen van behoorlijk bestuur of de nationale Ombudsman lijkt het "onderhandelend bestuur" de (rechts) positie van burger en maatschappelijke organisaties te bepalen". Daalder schreef al in zijn afscheidsrede uit 1993: "De overheidsbureaucratie is niet neutraal maar door en door politiek in alle geledingen" . Nick Huls ging nog een stap verder: "een actieve bureaucratie is tegenwoordig onmisbaar voor de oplossing van de meeste maatschappelijke problemen". Dat klinkt evident, alleen niet het verantwoordelijk bestuur, maar de bureaucratie - die rij onaanspreekbaren en niet verantwoordelijken krijgt hier de hoofdrol. Veel studies en nog meer beleidsplannen verschenen vol "win - win situaties" al dan niet in de vorm van "public private partnerships". Maar niemand repte over het collusie gevaar.

Nadat we het gedogen uit de jaren '80 achter ons hadden gelaten , bleken we ineens naadloos over te zijn gegaan naar horizontale bestuur en beleid. Deze nieuwe stijlfiguren zaten vol onderhandelen en dereguleren, en dat stimuleerde weer dat privatiseren. Vanuit het collusie-risico perspectief viel dit allemaal onder één paraplu: van publiek naar privaat.

Minister president Kok sprak van polderen, en ging dat in Amerika uitleggen. In feite was zijn boodschap: Nederland is een voorbeeld van een succesvolle democratie, juist vanwege haar gematigdheid, haar overlegstructuren, en haar tolerantie. Maar terwijl hij genoot van zijn optreden op het wereldtoneel, brak coalitiepartner VVD steeds grotere delen van dat publieke bestel af. Ik zeg het wat cryptisch.

De verschuiving van publiek naar privaat ging snel. Vóór we het wisten waren de posterijen privaat en was het spoor gesplitst in voor 
mij onbegrijpelijke stukjes. Naar het brede publiek toe werd alles gelegitimeerd in termen van efficiëntie enerzijds, en anderzijds met slogans als "social responsibility" , "corporate governance" of "good governance". Kortom, hoogtijdagen voor de bedrijfs ethiek. De Code Tabaksblat en haar voorgangers en opvolgers werden gepresenteerd met herkenbare argumenten als:

- Wij, kennen onze branches beter dan de overheid, dus geef ons de ruimte

- Wij nemen de overheid werk uit handen, dat scheelt hun tijd en geld, immers wij zijn van huis uit veel zuiniger en minder bureaucratischer dan de overheid.

- En sinds Parijs is daar de duurzaamheids bij gekomen. De private sector wil voorop lopen qua duurzaamheid, mits zij zelf mag uitmaken waar de haalbaarheids grenzen liggen. Kortom, erg onpartijdig was deze rechtvaardiging van dat eigen beleid niet, het was meer zelfrechtvaardiging. Collusie tussen privaat en publiek lijkt, overdrachtelijk gesproken, op institutionele intimiteiten die te ver gaan. Dat is fout, maar de plegers lijken het wel graag te doen.

Naast ons nationale erfgoed noem ik de Europese Unie als een risicovolle collusie-bevorderaar al kan men daar ook anders tegenaan kijken. Lang was Europa een werelddeel voor stratego-liefhebbers. Maar na de laatste wereldoorlog werd het steeds meer één gemeenschap. Eerst alleen voor kolen en staal, en later de rest. Dat verhaal is bekend....

Vanwege Europa moeten werkgevers en werknemers-organisaties steeds vaker naar Brussel om hun zaken te behartigen. Dat vraagt vooroverleg met Europese branchegenoten. Ook de werken van spindoctors en de lobbyisten verhuisden van de hoofdsteden naar Brussel. Op zich best, maar het risico op afglijden blijft groot. Vriendjespolitiek vindt hier een vruchtbare voedingsbodem zo is al vaker gebleken. Anderzijds, een Europa met zoveel lidstaten kan niet functioneren zonder veel, liefst discreet, vooroverleg. Om met 27 mensen tot een conclusie komen, kan men niet zonder. Bij de VN 
ziet men hetzelfde. Collusie is daar geen vooroverleg om iets illegaals af te schermen, maar vormt een onmisbaar institutioneel levens-elixer. Het belang van zo'n onderlinge verstandhoudings -afstemming zonder welke de VN, maar ook de Europese Unie niet zouden kunnen functioneren, is groot. Moet ík niet wat inbinden inzake mijn waarschuwen voor collusie als een fout instrument? Was mijn waarschuwende boodschap niet overdreven? Is collusie soms niet onvermijdelijk of een soort "minst slechte keus"?

In ons land lijkt veel collusie uitgelokt door de overheid die taken en plichten afstootte. Het gaat hierbij steeds om hetzelfde: minder Den Haag en meer handel voor de private sector.

Er waren al veel professionals op wie de overheid nóóit veel grip had. Denk bijvoorbeeld aan de bancaire sector of de accountancy, of aan de medische of juridische specialisten. Die waren er altijd al, en die waren altijd al duurder dan de publieke sector.

Maar nu schoven ook die nieuwe private diensten hun extra kosten en risico's door naar hun klanten. Zo ontstond er een gat tussen publiek en privaat. En dat gat werd groter toen bleek dat de overheid wel geschoven en gedelegeerd had, maar daar veel minder geld had bij gegeven. Er was een derde laag aan het ontstaan, naast publiek en privaat. Economen spraken in de dagen van Balkenende graag van de categorie "gezinnen". Ze waren er altijd al, als klant van de overheid. Maar nu werden ze vangnet voor als overheid en private sector beiden het niet meer konden bolwerken.

Hoewel de grote tendens was deregulering en privatisering (van publiek naar privaat), ging het soms ook de andere kant uit. Dat speelde als de private sector het niet meer aan kon.

Het jaar na de bank crash in VS van 2008, vielen kort daarna ook bij ons de meeste grote banken om en vroegen en kregen overheidssteun. Toen verwezen analisten onder andere naar de Canadese Jodie Freeman - intussen hoogleraar in Harvard - die daar veel over had geschreven. Ze stelde dat in het algemeen "privatisation of the public, but also a publicatisation of the private" 
heel nuttig en verfrissend kan werken voor zowel overheid als private organisaties, vooral in tijden van crisis. In feite gaat het dan om een soort filteren, het door een percolator persen, van "public law values into private law". Ze doelt dan op waarden als echte "transparency", "accountability", en scheiding der machten; waarden waar de private sector minder vertrouwd mee was. Maar dat ombuigen van privaat naar publiek ging bij haar verder. Naast dat aanhaken bij crises stelde ze ook als eis een actieve deelname van vakbonden, NGO's en aanverwante "public interest" groepen. Voor Freeman is een goede overheid, "een overheid die altijd leert". Die tijden van crises gebruikt ze om er beter van te worden. Maar ook publiek bestuur dat té lang zit, niets vernieuwt of leert maar op de winkel past, geeft aan dat het tijd is te privatiseren, overigens wel met behoud van dat meepraten door bonden en NGO's, hopend op optimale transparantie, en - zo wil ik er aan toe voegen - om het collusiegevaar op afstand te houden. Die link naar crisissen had ze nodig omdat het wel een gewichtige stap was, dat van privaat naar publiek, of omgekeerd. Ze spreekt van privatiseren als een soort reanimeren, frisse wind, nieuwe mensen etc.

Andere auteurs gingen verder en spraken van "strategisch" privatiseren of "strategisch" in de publieke sfeer terug brengen. Dat "strategisch" slaat dan op bijkomende nieuwe doelen. Tienhaara bv. koppelt de geld crisis aan de milieu crisis. En club in Londen die zich "The Green New Deal group" noemt, ging nog verder en koppelde de crediet crisis niet alleen aan klimaatverandering, maar aan zoiets als reorganisatie van de gas en olie markt, onder het motto: als we dan toch aan het schuiven zijn, doe het dan goed.

- Hoe meer "strategisch" men omgaat met dat privatiseren van het publieke of juist het in de publieke sfeer brengen van het private naar aanleiding van crises, des te vernieuwender wordt ook het effect op de juridische en politieke instituties. Mark Moore sprak in zijn boek "Creating public value: strategic management in Government" over een soort herwaarderen ; "recalibrating" van de relatie "publiek - privaat" noemde hij dat. 
Achteraf kan ik zeggen: daar was ik zelf ook aan toe. Waar ik jarenlang somber bleef vanwege de aanwezigheid van dat collusie gevaar, lijken de betogen van deze auteurs veel hoopvoller. Met name die Green New Deal group accentueert dat het in feite gaat om een oproep tot meer sociale verantwoordelijkheid, waar men nauwelijks meer omheen kan. Juist als men op tijd strategisch weet te switchen verzeilt men gemakkelijk in een situatie waarbij publiek en privaat elkaar aanvullen of minstens in balans houden. Mijn scepsis bv. tegen zelfregulering vervangen zij door een meer positieve en hoopvolle "trust dimension", gegarandeerd omdat "third parties" het proces bewaken. Die maken het echte verschil uit.

Een andere reden die publiek en privaat dichter naar elkaar toe duwt zonder verdachtmaking, is de informatie technologie. De problemen met een gestolen identiteit of nep accounts op facebook of twitter, gaan al heel ver. Straks weten we niet meer wat fake is en non-fake. Het begrip privacy lijkt op de helling te staan. Men kan het nog zo mooi juridisch formuleren, maar in feite kan iedereen overal gespot worden. Over die informatie is men zelf niet de baas, erger men weet vaak niet van het bestaan ervan. Er zijn legio open vragen rond internet gebruik. Voor internet moet men tenminste nog betalen, daar kan een jurist iets mee. Maar facebook, twitter en wat's ap zijn gratis. Kortom, wie is waar aanspreekbaar bij IT misbruik?

De gevolgen van het digitaliseren gaan snel, maar zijn tegelijkertijd zo verstrekkend dat hier publiek en privaat wel de handen ineen moeten slaan. Men heeft elkaar nodig. Organisaties zien net als de overheid hun geheimen niet graag op straat.

Ook elders komen ze elkaar tegen, bv. in tijden van coalitievorming en regeringsformatie. Allerlei publieke en private partijen en belangengroepen hadden hun wensen voor de toekomst, doorgestuurd naar de formateur. Dat heette geen "publieke zaak maken van private belangen", maar het nodigt de overheid wel uit om zich met private deelbelangen te bemoeien. In feite is de publieke zaak nooit zo machtig, als in dagen van formatie. Dat vraagt wel 
discretie, maar het is niet heimelijk of stiekem. Belangengroepen kunnen hun agenda's en loyaliteiten herschikken. En zij niet alleen. Het is geen toeval dat bv. zorgverzekeraar CZ samen met het gemeentebestuur van Den Haag de armoede in een aantal wijken wil aanpakken, als expressie van een totaal nieuwe aanpak.

Inderdaad dat is nieuw. CZ, de zorgverzekeraar, handelaar in illusies, die zich ineens gaat bemoeien met de gemeentelijke armoedebestrijding. De link tussen armoede en gezondheid klachten is allang bekend, maar nu ook meedoen inhoudelijk aan de preventie van die armoede is echt nieuw.

Ik begon mijn verhaal met organisatiecriminaliteit als machtsmisbruik, dat grenzenloos leek te kunnen groeien. Maar net als in Orwell's Animal farm, botste dit groeien op haar eigen vermeende grenzeloosheid. Zo kon ik hoopvol eindigen bij CZ in de de armoedebestrijding. Er zijn meer onverwachte voorbeelden van dit soort, maar daarover later meer.

Aan het eind van deze rede wil ik nogmaals Universiteit en Faculteit met al haar hartelijke bewoners bedanken voor zoveel jaar leerzame vriendschap.... 
LITERATUUR (selectie)

- FREEMAN, Jody, "The Private Role in Public Governance", N.Y.Law Review, 75, (543), 2000

- FREEMAN, Jody, “Extending Public Accountability Through Privatisation; From Public Law to Publicization", in, Michael L.D. Dowdle (Ed) Public Accountability; Designs, Dilemmas and Experiences, Cambridge Univ. Press, 2006

- GREEN NEW DEAL GROUP The, A Green New Deal: Joined-up policies to solve the triple crunch of the credit crisis, climate change and high oil prices, London: New Economics Foundation, 2008

- HEUVEL VAN DEN, Nico, H.L., De ambachtsgilden van 's Hertogenbosch voor 1629, Den Bosch: Jan Mosmans, 1946

- HEUVEL VAN DEN, Grat, "Corporate Crimes in East and West; in Search of Collusion", in Heather Strang \& Julia Vernon (Ed), International Trends in Crime: East meets West, Australian Institute of Criminologie, ACT, 1992

- HEUVEL VAN DEN, Grat, Onderhandelen of Straffen, Over organisatiecriminaliteit en overheidscontrole, Kluwer, Arnhem: Gouda Quint, 1993

- HEUVEL VAN DEN Grat, "Gepolitiseerde bureaucratie en corruptie in Nigeria and Indonesië", in Bruinsma F. e.a. (Ed) Precaire Waarden, Liber Amicorum voor prof. Mr. A.A.G.Peters, Arnhem: Gouda Quint BV, 1994.

- HEUVEL VAN DEN, Grat, Collusie tussen overheid en bedrijf, een vergeten hoofdstuk uit de organisatiecriminologie, oratie, Maastricht University, 1998

- HEUVEL VAN DEN, Grat, "The Parliamentary Enquiry on Fraud in the Dutch Construction Industry; Collusion as a concept between corruption and State - Corporate Crime", Crime, Law and Social Change, 44; 133 /153, Springer, 2006

- HEUVEL VAN DEN, Grat en NI KETUT SUPASTI DHARMAWAN, “Corporate Responsibility and Corporate Crime Control in the 
Tourism Industry", in Sustainable tourism and law, Faure, M. , Ni Ketut Supasti Dharmawan and I Made Budi Arsika (Ed), Eleven I.P: The Hague, 2014

- HULS, Nick, "De Onderhandelende Ambtenaar", Stout, H. en Hoekema, A.J.Onderhandelend Bestuur, Zwolle: Tjeenk Willink, 1994

- LUYENDIJK, Joris, Dit kan niet waar zijn, Onder Bankiers, Amsterdam, Atlas - Contact, 2015

- LIJPHART, Arend, THE POLITICS OF ACCOMMODATION, Berkeley: Univ. of California Press, 1968

- MOORE Mark, Creating Public Value: Strategic Management in Government, Harvard Univ. Press, 2010

- PONTELL, Henry n. and CALAVITA, Kitty, "White-Collar Crime in the Savings and Loan Scandal", THE ANNALS OF THE AMERICAN SOCIETY OF POLITICAL AND SOCIAL SCIENCE, 525, Sage,1993 